\title{
PERANCANGAN SENI PATUNG LANDSCAPE ECO-CULTURE DESA WISATA SELOREJO DAU MALANG MELALUI PROGRAM KEMITRAAN DESA
}

\author{
Ponimin*, Mitra Istiar Wardhana, Ahmad Taufiq, Astri Anindya Sari \\ ponimin.fs@um.ac.id \\ Jurusan Seni dan Desain, Fakultas Sastra, Universitas Negeri Malang \\ Diterima 6 Oktober 2020, dipublikasikan 31 Oktober 2020
}

\begin{abstract}
Abstrak
Program kegiatan kemitraan desa wisata Selorejo Dau Malang, oleh tim PPDM 2020 LP2M UM bertujuan untuk membantu masyarakat dalam perancangan ikon visual berupa seni Patung landscape bertema selamat datang di kawasan desa wisata Selorejo. Sehingga dapat menambah daya tarik wisatawan. Metode realisasi program meliputi persiapan kegiatan, pelaksanaan kegiatan kreatif perancangan dan pembutan karya patung, evaluasi kegiatan, dan penyimpulan akhir kegiatan. (1) Proses persiapan meliputi koordinasi tim bersama mitra pengguna guna menghasilkan konsep dan rancangan patung landscafe, serta persiapan bahan dan peralatan. (2) Melaksanakan kegiatan proses pembuatan patung landscape. Yakni merumuskan konsep kegiatan, melaksanakan proses pembuatan rancangan gambar desain, pembuatan elemen-ellmen visual pendukung, menentukan bentuk, mewujudkan rancangan menjadi bentuk patung landscape di lokasi desa wisata. (3) Analisis hasil kreasi seni patung. Kegiatan menghasilkan satu set seni patung landscape didisplay di bumi perkemahan Selorejo Lestari. Patung tersebut berbentuk sosok figur seorang Laki-laki dewasa bersama anaknya sedang berdiri di atas pedestal, dengan membawa setangkai ranting pohon jeruk.
\end{abstract}

Kata Kunci: Desa Wisata Selorejo, Seni Patung, Landscape

\section{PENDAHULUAN}

Pengembangan suatu kawasan wisata desa dengan tata lingkungan yang artistik dan ramah lingkungan memiliki peran penting di dalam mewujudkan kawasan tersebut menjadi menarik dan memiliki citra estetik. Ketika suatu kawasan wisata tersebut dirancang dengan perencanaan yang matang maka akan memiliki kekuatan secara ekonomi dan secara kultural (Costa \& Ferrone, 1995).

Desa Selorejo di kecamata Dau kabupaten Malang merupakan desa yang sedang menggali potensi desanya untuk diberdayakan menjadi desa wisata (Healy, 1994). Dengan kekuatan potensi alam yang eksotik dan produktif, serta ditambah semangat masyarakatnya dalam mewujudkan cita-cita tersebut tentu akan menjadi mimpi yang tercapai (Darbellay \& Stock, 2012). Eksotika alam yang didukung oleh geografis kawasan, berada pada lereng timur gunung Kawi dan lereng selatan gunung Panderman, sehingga memiliki tampilan yang eksotik ketika di pagi dan siang hari. Alam pegunungan dan ladang pada kawasan lereng timur gunung Kawi merupakan keunggulan dari sisi penampilan eksotika kawasan tersebut. Karena desa tersebut berada lereng ketinggian 900m dari permukaan air laut. Letak geografis desa yang berada di lereng timur gunung Kawi serta berdekatan dengan kawasan kota Batu dan kota Malang menjadikan daerah ini ekonominya tidak pernah berhenti. Yakni ekonomi untuk wisata dan pemenuhan kebutuhan pangan dari kehidupan bercocok tanam dari hasil bertani kebun dan sawah ladang. Desa ini memiliki penduduk \pm 1.200 .000 orang yang menempati dusun Selokerto, Gumuk, dan dusun Krajan. Ketiganya memiliki potensi yang sama yakni masyarakatnya menekuni hidup bercocok tanam ladang.

Produk pertanian dari tanaman ladang yang menjadi unggulan dan tak pernah berhenti adalah jeruk dan menjadi tulang punggung perekonomian masyarakatnya (Angelini \& Castellani, 2019). Hal ini didukung oleh kondisi kondisi tanah yang subir dan cocok untuk jenis tanaman tersebut serta kondisi irigasi air dari sungai yang tidak pernah berhenti. Sehingga lahan pertanahan tersebut menjadi subur 
untuk kebutuhan kebutuhan bercocok tanam. Dalam satu tahun proses panen dapat berlangsung bergantian tergantung dari masa tanam yang mereka lakukan.

Kekuatan lainnya adalah budaya agraris bercocok tanam buah jeruk, sayur-sayuran, merupakan unggulan dari kegiatan agrarisnya. Ditunjang dengan sikap masyarakat yang produktif maka desa ini memiliki potensi untuk dikembangkan untuk menjadi desa ecocultural maupun argocultural (Xu, Huang, \& Zhang, 2018). Lingkungan alam dengan air yang mengalir membelah desa menjadikan kawasan tersebut lahannya tak pernah kosong untuk ditanami. Jeruk yang ditanam di pekarangan dan ladang membuat desa ini nampak produktif. Kondisi desa yang nyaman, aman, menjadikan desa ini berpotensi untuk dikembangkan ekonominya ke arah yang lebih baik. Masyarakatnya yang hidup dari agraris dari berkebun dan berbuah tentu akan menjadikan kawasan tersebut berkembang lanjut menjadi desa wisata yang berbasis ecocultural (Darbellay \& Stock, 2012). Masing-masing keluarga umumnya memiliki lahan tanaman jeruk kurang lebih seperempat hektar yang berada di pekarangan lereng timur gunung Kawi. Kondisi ini membuat penduduknya tidak pernah mengalami kemiskinan. Oleh karena itu desa ini terasa nyaman untuk disinggahi karena udaranya yang bersih, sejuk dan maysarakatnya yang ramah dan bersahaja (Costa \& Ferrone, 1995). Selain hal tersebut, para warganya juga saling membantu antara petani satu dengan petani lain dalam proses bertanam maupun panen. Tentu saja dampak dari program tersebut membawa nilai positif terhadap perekonomian masyarakat maupun kehidupan sosial budaya (Xu et al., 2018). Peran aparat desa yang dikomandani oleh kepala desa beserta jajarannya dituntut aktif dalam menjalin hubungan dengan pihak luar guna memecahkan persoalan pengembangan desa wisata secara bersama. Dengan semakin giatnya masyarakat dan aparat desa untuk meningkatkan kualitas sebagai desa wisata maka peran aktif tersebut juga harus semakin ditingkatkan yakni dalam penguasaan aspek teknis dan manajerial dalam pengelolaan desa wisata (Cerisola, 2019).

Mereka sangat bersemangat untuk meningkatkan desanya sebagai desa berbasis ecocultural. Yakni dengan melakukan pembenahan lingkungan alam dan lingkungan pemukiman yang menjadi andalan dari desa tersebut. Yakni untuk membangun citra desa melalui pembangunan taman kawasan desa, sanitasi, irigasi, infrastruktur yang lainnya dan pelayanan kepada masyarakat. Mereka menyadari bawha pembangunggan fasilitas desa perlu dikembangkan guna meningkatkan citra desa agar lebih dikenal. Selain itu juga agar lebih terdorong daya tarik wisatanya untuk berkunjung ke desanya (Darbellay \& Stock, 2012). Mereka menyadari bahwa citra estetik desa merupakan modal utama dalam pengembangan desa tersebut. Mereka juga menyadari peran serta masyarakat desa secara aktif dalam membangun citra desanya yang tidak hanya mengandalkan aspek produktifitas tanamannya saja (Warren, 2013). Akan tetapi juga penting menumbuhkan aspek estetik desa yang berupa ikon-ikon artistik yang harus dipajang di kawasan tersebut. Dengan adanya ikon-ikon estetik yang mencitrakan desa tersebut sebagai desa wisata agro-cultural ataupun eco-wisata. Sebut saja seperti Kampung Naga yang merupakan kampung adat yang saat ini bertransformasi juga menjadi tempat wisata budaya dan eco-wisata melalui kearifan lokalnya (Wiradimadja, 2018). Masyarakat adat dan juga masyarakat sekitar menjaga kampung tersebut agar tidak dibangun dengan pembangunan modern (Wiradimadja et al., 2018), sehingga jenis dan arsitektur bangunan disana memiliki ciri khas yang estetik dan ikonik. Pengembangan kawasan wisata desa tidak cukup bermodalkan pada produktifitas jeruk saja, tetapi juga perlunya menciptakan citra desa secara berkelanjutan (Angelini \& Castellani, 2019).

Dengan demikian, ketika desa ini mempropagandakan sebagai kawasan wisata argo-cultural maupun wisata eco-cultural, maka menanti kepedulian pihak lain untuk mengulurkan tenaga, pikiran, dan kreatifitasnya dalam memecahkan persoalan yang dihadapi bersama masyarakat setempat sebagai mitra. 


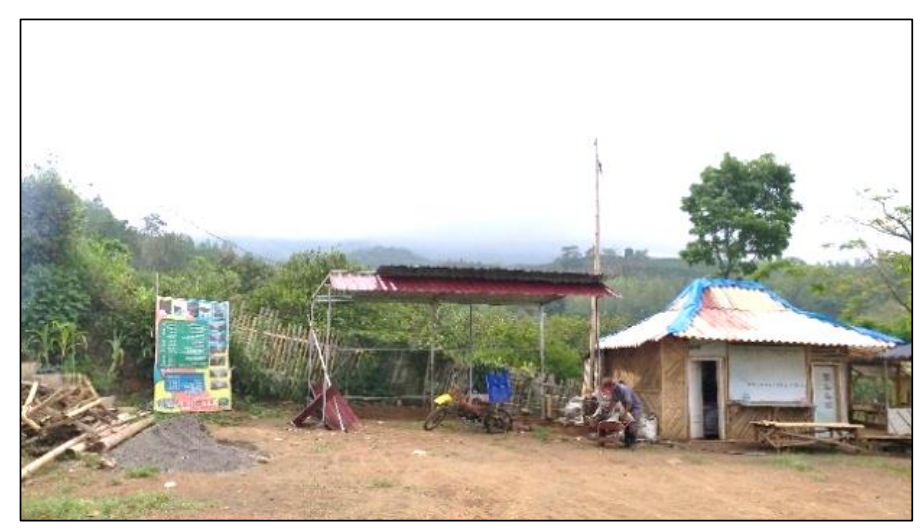

Gambar 1 Tampak Sisi lain di kawasan desa Selorejo Dau, Malang yang perlu mendapatkan sentuhan artistik visual (foto tim pelaksana program PPDM 2020).

Mereka menyadari bahwa kurangnya kemampuan dalam melaksanakan pengembangan wisata desa. Pengembangan desa wisata perlu ikon-ikon visual guna memperkuat citra desa wisata Selorejo. Oleh karena itu berdasarkan hasil pengamatan tim pelaksana program PPDM LP2M UM 2020, tim ini perlu andil dengan menyumbang pikiran, dan tindakan kreatif guna membantu kawasan tersebut. Hasil pengamatan di lapangan oleh tim tersebut menunjukan masyarakat desa tersebut sangat bersemangat untuk memajukan desanya melalui pengembangan wisata (Chen \& Rahman, 2018). Sehingga tim PPDM LP2M UM merasa terpanggil untuk membantu memecahkan persoalan tersebut dengan melakukan perancanga desain dan penerapan patung landscape yang dapat memperkuat tema wisata di kawasan tersebut. Citra Kurangnya pengalaman artistik dalam berkreasi dalam menciptakan patung landscape artistic di kawasan desa tersebut, maka mereka berharap ada lembaga lain yang mau mengulurkan bantuan memecahkan masalah tersebut. Oleh karena itu dengan realisasi program ini mereka sangat antusias menjadi mitra progam PPDM LP2M UM, sehingga apa yang menjadi cita-cita mereka dapat terpenuhi. Oleh karena itu mereka juga antusias untuk membantu agar dapat terealisasi program pembuatan seni patung landscape tersbut (Costa \& Ferrone, 1995). Konsep dan desain patung landscape dirancang dengan bentuk yang memepertimbangkan aspek artistik dan keserasian lingkungan alam lokal (IImi Solihat, 2017).

Dalam pelaksanaan konsep dan rancanga desain serta penerapannya tersebut tentu akan mengalami permasalahan teknis yang perlu dipecahkan. Permasalahan tersebut meliput: (1). Perumusan konsep perancangan seni patung landscape untuk memperkuat citra desa wsata Selorejo. (2). Merealisasi konsep dan rancangan menjadi bentuk patung di lokasi wisata bersama peran masyarakat setempat.

\section{METODE}

Kegiatan untuk memecahkan masalah mitra desa Mitra yang berupa perancangan desain dan penerapan seni patung landscape di desa wisata Selorejo Dau Malang memerlukan metode pemecahan masalah. Hal tersebut meliputi beberapa tahapan. (1). Jalinan Kerjasama antara desa mitra pengguna dan tim PPDM LP2M UM. Jalinan Kerjasama yang dimaksud adalah pelibatan mitra desa untuk andil dalam proses kreatif mewujudkan produk patung landscape. Yakni bagaimana desa mitra memberi kontribusi terhadap keberlangsungan kegiatan dalam menciptakan karya patung Landscape icon desa Wisata Selorejo. Yakni dengan memberi peran aktif masyarakat atau pemerintah desa untuk berpartisipasi pada proses merealisasi produk seni patung, finishing, hingga perawatan. (2). Aksi kerja kreatif; Yakni proses merealisasi ide/ gagasan oleh tim PPDM, dimulai dari persiapan menggali ide, merumuskan konsep, persiapan alat, bahan, mewujudkan karya, finishing karya, hingga perawatan karya denga melibatkan mitra desa sasaran program (Ponimin, 2019). (3). Evaluasi hasil program; kegiatan ini meliputi diskusi antara tim PPDM dan Desa mitra sebagai pengguna produk hasil kegiatan kreatif, guna memecahka masalah yang dihadapi selama program berlangsung serta 
mendapatkan masukan dari desa mitra pula. (4). Analisis hasil kegiatan kreatif pembuatan patung landscape.

\section{HASIL DAN PEMBAHASAN \\ Koordinasi perancangan dan penciptaan patung landscape di kawasan desa wisata Selorejo}

Suatu kawasan desa wisata agar memiliki daya Tarik terhadap wisatawan tentu perlu didukung oleh beberapa hal yang terkait dengan daya Tarik yang dbangun dari karakter visualnya, yakni melalui pengembangan ikon-ikon visual yang ada di kawasan desa tersebut. Ikon-ikon visual yang dimaksud adalah Karya seni rupa, baik berupa seni patung, taman, tampilan kondisi tata lingkungan yang asri. Kondisi tata lingkungan hendaknya memiliki nilai artistic serta hal-hal lain yang memperkuat karakter artistik atau karatkter visual dari desa tersebut (Rendy Widi Prasetyo \& Nur Wakhid Hidayatno, 2017).

Oleh karena itu pada pelaksanaan program PPDM LP2M UM 2020 yang bertujuan untuk memperkuat desa wisata Selorejo sebagai kawasan desa wisata yang berbasis Eco culture, maka telah dilakukan kegiatan kerjasama dengan tim pengembang wisata di kawasan desa tersebut yang terdiri dari pemuka masyarakat dan para pemangku kepentingan termasuk pemerintahan desa.

Pada kegiatan tersebut telah merealisasai kegiatan yang berupa perancangan dan penerapan seni patung landscape ikon desa wisata Selorejo. Berbagai hal terkait kegiatan kreatif yang bertujuan untuk menciptakan produk artistik berupa patung landscape tersebut, tentu saja dalam pelaksanaannya membutuhkan kerja kreatif dan aktif. Dari kegiatan yang berlangsung telah dilakukan beberapa tahapan yakni tahapan persiapan, tahapan pelaksanaan, dan tahapan evaluasi serta analisis hasil kreatif pembuatan patung landscape.

Pada tahap awal adalah persiapan kegiatan. Pada tahap tersebut dilakukan persiapan dan perencanaan konsep dan gambar desain, serta rencana merealisasikannya kedalam wujud karya patung. Pada tahap awal ini juga mempersiapkan bahan serta peralatan dan bahan yang digunakan dalam proses kreatif mewujudkan seni patung tersebut. Pada proses persiapan juga terkait dengan koordinasi dengan koordinasi antara tim pelaksana PPDM LP2M UM dan tim dari desa setempat. Yakni koordinasi terkait dengan bagaimana pelaksanaan program tersebut dapat dilakukan secara bersamasama masyarakat, yakni dalam merealisasikan kegiatan. Oleh karena itu dalam proses merealisasi kegiatan telah mensepakati tentang konsep dan gambar bentuk karya, material yang digunakan, peralatan serta rancangan tempat atau lokasi patung tersebut serta hal-hal mana yang harus dikerjakan oleh mitra desa atau tim PPDM LP2M UM.

Pada tahapan perencanaan yang berupa koordinasi ini tim dari tim desa setempat sangat antusias untuk membantu memecahkan persoalan ini. Oleh karena mereka memahami bahwa ha ini adalah untuk kepentingan pengembangan wisata desanya. Oleh karena itu dari pihak aparat desa, tokoh-tokoh masyarakat sangat antusias membantu dalam pelaksanaan program ini. Hal ini ditunjukkan ketika koordinasi dengan tim dari PPDM LP2M UM ditunjukan dengan semangatnya ketika dalam diskus maupun kerja yang sesungguhnya. Mereka sangat senang ketika dibutuhkan dalam proses perwujudan karya ini. Pada koordinasi ini telah disepakati bahwa tim PPDM LP2M UM telah merancang konsep dan gambar desain patung landscape dengan ikon desa wisata Selorejo. Yakni berupa bentyuk patung figur sosok laki-laki yang sedang memetik buah jeruk bersama anaknya.

Sosok figur laki-laki tersebut menjadi tema utama yang direalisasikan menjadi bentuk patung landscape di desa wisata tersebut. Pada kegiatan ini tim dari mitra desa telah sepakat untuk mempersiapkan pedestal atau landasan patung sebagai tempat pemajangan patung di lokasi. Pada kegiatan ini menunjukkan bahwa mereka sangat mendukung dan memberikan apresiasai terhadap apa yang telah dirancang dan dikonsep serta diwujudkan dalam bentuk patung ikon tersebut. Selanjutnya tim LP2M UM sebagai perancang gambar desain dan mewujudkan bentuk patung tersebut. 


\section{Kreasi Seni Patung Landscape Kawasan Desa Wisata Selorejo Persiapan Alat dan Bahan}

Dalam merealisasi program perancangan dan penerapan patung landscape ikon wisata desa Selorejo diperlukan peralatan dan bahan. Alat dan bahan merupakan faktor penting dalam mewujudkan produk tersebut. Hal tersebut berkaitan dengan persiapan material yang digunakan untuk mewujudkan patung tersebut, baik saat dibuat di stodio maupu saat di kemas dilokasi yang telah ditentuan. Peralatan dan bahan ini berkaitan dengan material-material utama dan material-material pendukung dalam merealisasi karya, baik untuk membentuk patung figur utama maupun pedestal landasan patung hingga bahan dan peralatan finishingnya. Sebelum proses pembuatan terdapat peralatan dan bahan yang dipersiapkan dari tim LP2M UM dan oleh tim mitra wisata desa Selorejo. Adapun bahan tersebut meliputi bahan material semen, pasir, tanah liat, batu bata-batu kali, dolosit, dolomit, cat tembok, cat minyak dan beberapa bahan lain untuk mewujudkan karya hingga proses finishing. Bahan-bahan tersebut disediakan oleh tim pelaksana dari LP2M namun yang berupa batu kali dipersiapkan oleh tim mitra desa wisata.

Selain bahan juga deperlukan peralatan sebagai cara untuk merealisasai rancangan. Adapun peralatan tersebut meliputi peralatan gambar desain dan peralatan membentuk karya patung hingga pemajangannya, Peralatan untuk menggambar rancangan desain meliputi seperangkat komputer, meja gambar, pensil dan peralatan lain. Adapun peralatan untuk mewujudkan karya adalah peralatan terkait pembuatan konstruksi rancangan patung dan pembentukan patung. Peralatan tersebut meliputi peralatan las, alat-alat pertukangan bangunan, serta alat pembentuk figur patung yang berupa butsir untuk membuat patung maupun finishing patung. Peralatan ini dipersiapkan oleh tim LP2M yang tergabung dalam PPDM tahun 2020 dan peralatan pembuatan pedestal patung yang dipersiapkan oleh pihak mitra desa wisata misalnya saja tangga pemajangan dan pengangkutan patung saat perakitan di lokasi.

\section{Proses Gambar Desain Seni Patung Landscape Desa Wisata Selorejo.}

Proses merealisai konsep dan gambar desain bentuk karya patung landscape ikon desa wisata menjadi wujud karya patung landscape diperlukan kegiatan kreatif berkarya. Proses kreatif merealisai seni patung tersebut adalah suatu kegiatan mewujudkan gagasan maupun konsep karya seni patung lanskap desa wisata selorejo kedalam wujud sebenarnya agar dapat terealisasi secara nyata di desa tersebut sebagai desa Eco Wisata atau Agro Wisata. Proses mewujudkan meliputi merancang sketsa bentuk karya yang terdiri dari gambar rancangan patung yang digambar teknik digital dikombinasikan dengan teknik manual. Rancangan ini menghasilkan alternatif bentuk karya yang nanti akan diwujudkan dalam karya sesungguhnya. Rancangan karya yang berupa gambar sketsa ini dilengkapi dengan ukuran maupun teknis pengerjaan serta material yang digunakan. 


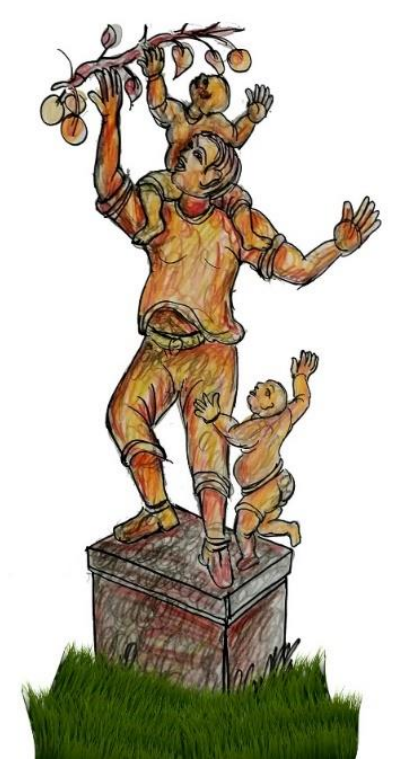

Tabel 2. Desain alternatif desain patung landscape untuk kawasan desa wisata Selorejo, bertema panen jeruk (gambar oleh Ponimin ketua tim pelaksana program PPDM 2020)

Pelaksanaan pembuatan karya patung dan penerapannya pada lokasi yang ditentukan. Proses mewujudkan dari bentuk gambar desain menjadi bentuk yang sebenarnya membutuhkan energi kreatif yang kuat agar karya tersebut dapat terwujud secara nyata dan tidak ada kendala. Pada kegiatan kratif tentu saja tidak serta merta dapat dilakukan secara serampangan tapi memerlukan pemikiran kreatifitas dari tim LP2M karena terdiri dari dosen dari bidang Seni Rupa maupun Teknik. Pada proses kegiatan karya ini melalui beberapa tahapan yaitu pertama pembuatan gambar desain rancangan karya sesuai dengan ukuran yang sebenarnya.

Rancangan gambar desain ini dengan ukuran tinggi 3 meter, dengan pedestal 1, $5 \mathrm{~m}$. Pada kegiatan ini dibuat di studio seni rupa Universitas Negeri Malang. Rancangan gambar ini dibuat dengan teknik manual dengan media kertas manila. Rancangan gambar desain patung ini juga berfungsi mempermudah skala perbandingan dari karya tersebut agar sesuai dengan ukuran yang sebenarnya. Gambar skala yang dibuat tersebut memuat gambar anatomi patung dan elemen-elemen detail bentuk, serta elemen struktur utama dari bentuk patung tersebut. Gambar desain rancangan dibuat dengan skala patung yang sesunggunya agar tidak terlewatkan dan terlepas dari bentuk dan ukuran yang sebenarnya. Pada proses pembuatan ini tim pelaksana selalu mencari kemungkinan-kemungkinan yang keterkaitan teknis pengerjaan. Baik beraitan dengan material untuk pembuatan karya serta konstruksi bentuk karya. Baik yang menyangkut keseimbangan, anatomi bentuk, dan kekuatan konstruksi pemajangan diatas pedestal. Selanjutnya pada proses pembuatan rancangan mal yang sebenarnya ini memperhatikan hal-hal keamanan ketika dipajang. Oleh karena itu pertimbangan konstruksi pada rancangan gambar ini juga memperhatikan hal-hal tersebut. Setelah rancangan skala gambar desain ini selesai, maka diwujudkan dalam bentuk nyata.

\section{Pembentukan karya dan Display patung Landscape}

Perwujudan karya dari rancangan gambar ke produk karya patung lanscape patung ikon desa wisata Selorejo juga meliputi beberapa tahapan. Tahapan pertama yakni dilakukan oleh tim bersama masyarakat mitra desa wisata untuk pembuatan kerangka konstruksi patung. Pebuatan konstruksi kerangka terbuat dari kawat besi cor berukuran 0,6 cm, serta 10, cm. Konstruksi Besi tersebut dibuat sebagai kerangka penyangga bentuk anatomi bentuk patung, agar karya tersebut memiliki kekuatan yang sesuai dengan beban penyangga bentuk patung tersebut. Oleh karena itu dalam rancangan konstruksi ini rangkaian kwat besi cor beton terdiri dari ukuran tersebut dirakit menggunakan las serta rangkaian kawat bendrat sesuai dengan global bentuk patung Pada proses perakitan ini memerlukan 
ketelitian perbandingan rancangan bentuk patung, yang meliputi susunan jarak antara kawat besi satu dengan besi yang lainnya. Pada proses ini tentu saja ikatan-ikatan antar kawat besi tersebut dipastikan benar-benar kuat, ketika ditempelkan adonan pasir dan semen tersebut pada kawat kasa global patung. Pada rangkaian besi ini untuk menentukan rancangan anatomi bentuk tersebut bener-benar diperhitungkan dengan cermat agar kekuatan dan bentuk anatomi tercapai sesuai yang dikehendaki. Oleh karena itu penggunakan kawat besi cor dipilih dan ditata yang mudah pengaturannya dalam proses pembengkokan kawat besi cor tersebut. Pada proses pembuatan kerangka patung ini, pentingnya mempertimbangkan aspek kekuatan dari karya tersebut ketika dipasang. Oleh karena susunan rangkaian kawat besi ini harus benar-benar memenuhi standar rangkaian kerangka konstruksi bentuk patung tersebut (Diah, Pratiwi, 2016).

Setelah konstruksi kawat besi cor selesai, selanjutnya membuat rangkaian bagian yang akan ditempeli adaonan semen dan pasir, yakni berupa lapisan kawat kasa. Pada proses pembuatan rangkaian kawat saringan kasa sebagai global bentuk patung tersebut dengan cara diikat kawat bendrat pada rangkaian konstruksi besi. Pada proses tersebut tim peneliti bersama dengan tim mitra desa mempertimbangkan aspek anatomi serta kekuatan kunstruksi patung pula. Apabila pengikatan konstruksi besi dengan kawat kasa kurang kencang, maka adonan pasir dan semen akan mudah terlepas. Proses pengikatan kawat kasa ini dibuat dengan jarak yang tidak terlalu rapat. Namun tetap memiliki kekuatan yang cukup ketika dilakukan proses penempelan adonan semen dan pasir.

Ketika semua rangkaian konstruksi besi dan kawat kasa ini selesai maka dilanjutkan dengan proses pelepoan atau penempelan adonan semen dan pasir pada permukaan dari bentuk patung tersebut. Proses ini dilakukan dengan perbandingan adonan semen dan pasir. Untuk ukuran 1 semen, sedangkan 2 pasir. Hal ini berpengaruh juga pada keliatan adonan pasir tersebut ketika ditempelkan, sehingga tidak lepas dengan kawat kasa tersebut. Oleh karena itu percampuran dari bahan-bahan tersebut yaitu pasir dan besi ini harus benar-benar homogen, sehingga ketika ditempelkan pada kasa tidak lepas meskipun sudah kering. Proses ini disebut pembuatan global patung yang menggunakan material semen dan pasir. Hal ini dilakukan selama beberapa hari agar pembuatan global patung sesuai dengan bentuk aslinya, sebelum pembuatan proses detail bentuk patung. Proses pembuatan patung selanjutnya yaitu pendetailan bentuk. Proses ini menggunakan cetok kecil dan butsir pembuatan patung. Proses pembutsiran dilakukan dengan cermat dan hati-hati agar sesuai dengan rancangan gambar agar sesuai dengan yang telah ditentukan. Proses pembuatan detail secara perlahan dan cermat karena menyangkut masalah artstik dari patung tersebut (Sukaya, 2009). Pada saat pembuatan ini tim LP2M memperhatikan aspek artistic. Sedangkan tim mitra desa memperhatikan arahan tim LP2M UM agar memiliki pengalaman dari proses pembuatan patung ini.

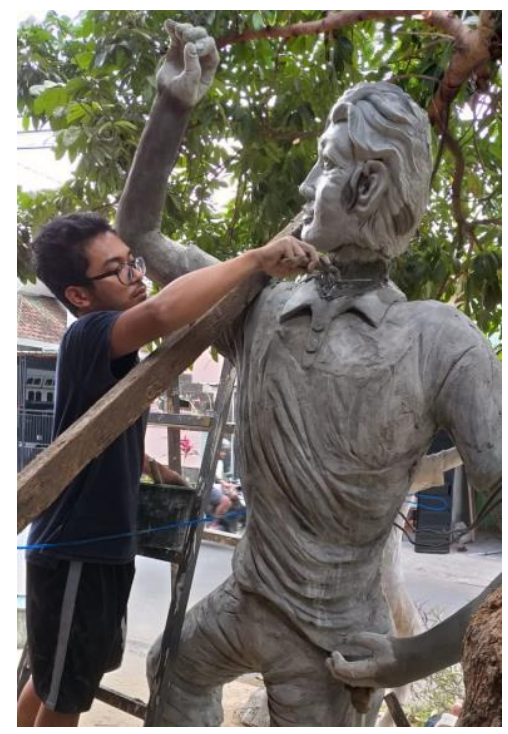

Tabel 3. Proses pembentukan patung secara manual (foto tim program PPDM LP2M UM 2020) 
Selanjutnya proses finishing; Proses tersebut menggunakan cat yang tahan air karena patung tersebut diletakkan di area terbuka atau eksterior. Langkah pertama menggunakan lapisan epoxy yaitu dengan dempul dulu pada permukaan patung agar daya resapnya tidak terlalu tinggi, selanjutnya menggunakan sprayer agar benar-benar rata dan karakteristik dari tekstur tersebut benar-benar nampak dan artistik. Pada tahap berikutnya yaitu proses perakitan patung pada lokasi tempat wisata atau di lanskapnya. Proses perakitan ini dilakukan dengan mengangkat bentuk patung yang dibuat di studio tadi, kemudian dipindahkan ke ruang terbuka yaitu pada pedestal patung di lokasi wisata dengan cara merakit dengan teknik las pada pedestal di bagian atas kemudian dilanjutkan dengan melepo permukaan yang masih tampak besinya hingga karakter visualnya benar-benar kuat dan sudut pandang dari patung tersebut sesuai dengan aspek-aspek artistik. Proses ini banyak melibatkan desa mitra agar mereka memiliki pengalaman dalam mengembangkan pada patung-patung berikutnya. Pada tahap akhir adalah menyempurnakan keseluruhan tampilan patung di lokasi. Baik itu pengecatan maupun pada penyempurnaan bagian anatomi bentuk patung yang kurang tepat pada saat didisplay di lokasi tersebut.

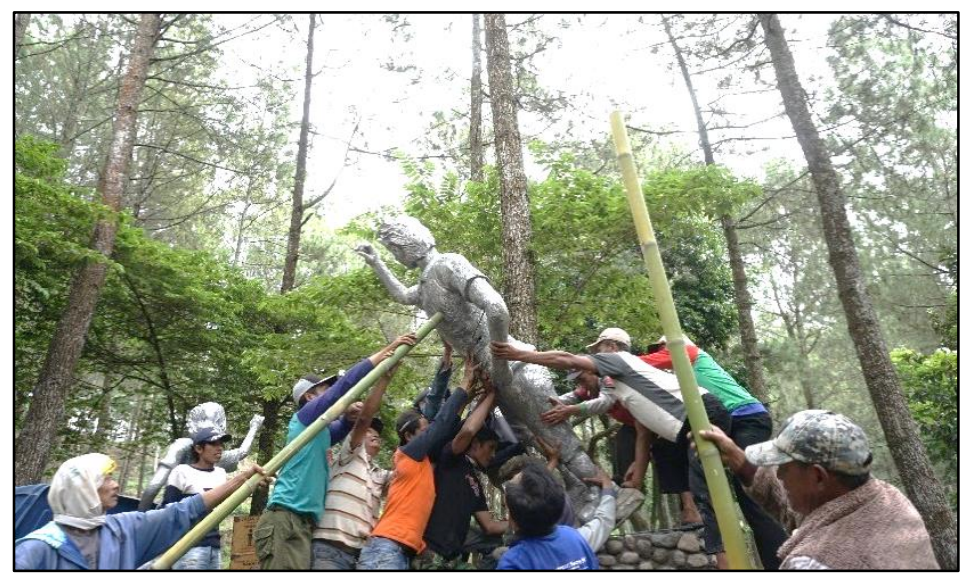

Tabel 4. Proses Pemajangan hasil kreasi patung landscape bersama desa mitra di kawasan wisata perkemahan Bedengan Selorejo (foto Tim PPDM LP2M UM 2020).

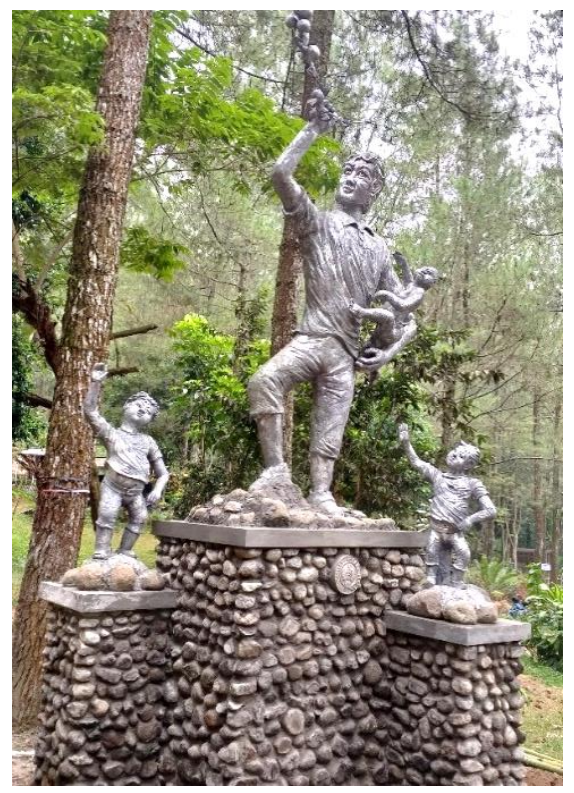

Tabel 5. Seni Patung landscape hasil kreasi bersama desa mitra telah terpajang di kawasan wisata perkemahan Bedengan Selorejo (foto Tim PPDM LP2M UM 2020). 


\section{Analisis}

Hasil kreasi patung landscape. di suatu kawasan wisata memiliki peran penting dalam menciptakan citra dari kawasan tersebut. Citra ini akan teringat bagi para wisatawan yang mengunjungi kawasan tersebut (Rowland \& Biocca, 2002). Selanjutnya akan menjadi menjadi kenangan yang menyenangan atau menjadi memori buruk baginya. Oleh karena itu perancangan seni patung landscape diciptakan memberi dampak artistik pada ruang ekterior, memperkuat (Dharsono, 2016). Pada sisi lain dapat mempertkuat karakter ruang publik desa wisata, serta peningkatan ekonomi dalam pengelolaan kawasan wisata tersebut (Ebejer, 2019). Pada sisi lain perancangan seni patung tersebut hendaknya dibuat menggambarkan keunikan desa wisata tersebut.

Selorejo merupakan desa wisata dengan alam perbukitan, serta ladang yang terhampar luas di lereng timur gunung Kawi. Potensi kesuburan lahan pertanian dengan agro bisnisnya berupa tanaman jeruk merupakan sumber perekonomian masyarakat setempat yang utama. Selama ini pengelolaan potensi tersebut memang sudah dikembangkan oleh tokoh masyarakat beserta aparat pemerintahan desa yang tergambung dalam lembaga pengelola desa wisata Selorejo sejak 10 tahun terakhir. Tim pengelola desa wisata tersebut sangat berharap kepada pihak lembaga lain untuk dapat membantu memecahkan permasalahan pengembangan desa wisata yang telah dirintisnya. Mereka membutuhkan uluran tangan aksi kreatif dari pihak lain dalam memperkuat karakter tampilan desa wisata yang sedang dikelolanya. Mereka menyadari bahwa masih banyak hal-hal yang perlu dikembangkan untuk memperkuat karakter desa wisata tersebut. Akan tetapi mereka tidak memiliki kemampuan ketika ingin mengembangkan kawasan tersebut agar lebih berkarakter, yang selanjutnya berdampak pada peningkatan wisatawan yang datang ke lokasi. Mereka menyadari bahwa ketika mengembangkan desa wisata perlu kemasan artistik yang kuat Pada program pengabdian kepada masyarakat yang diprakarsai LP2M UM, tim yang tergabung dalam PPDM 2020 telah bersinergi dengan pihak pengelola untuk memecahkan permasalahan yang tengah dihadapi. Kawasan tersebut semakin hari semakin ramai dikunjungi oleh wisatawan lokal maupun regional yang ingin menikmati alam desa yang masih asri dan alami tersebut. Di kawasan wisata desa tersebut tempat-tempat strategis namun belum menggamabrkan hal ikonik desa wisata dengan karakter yang khas (Beardsley \& Finn, 1996). Kawasan tersebut perlu ada seni patung landscape ikonik yang dapat memperkuat karakter desa wisata dengan tema ecokultural terkait pertanian jeruk, atau berupa bentuk seni patung dengan tema tersebut.

Oleh karena itu hal-hal yang terkait dengan ikonik visual desa wisata yang dapat ditampilkan pada kawasan tersebut yakni telah diciptakannya rancangan patung landscape dikawasan tersebut oleh tim PPDM LP2M UM. Rancangan dan penerapan ciptaan seni patung tersebut terealisasi atas dukungan masyarakat setempat bersama tim pengelola desa wisata Selorejo. Yakni berupa rancangan bentuk seni patung sosok laki-laki sedang mengangkat atau meraih buah jeruk dengan anaknya dengan posisi berdiri sebagai tanda bahwa dikawasan tersebut adalah dengan lingkungan petani jeruk. Tema rancangan seni patug tersebut sesuai hasil diskusi yang dilakukan secara bersama tim pengelola desa sebagai mitra program PPDM 2020 LP2M UM. Pada proses pembuatan dengan melibatkan dengan tim mitra agar memiliki pengalaman artistik serta pemahaman suatu ruang publik yang harus dimunculkan melalui ikon seni rupa yang berupa seni patung ruang publlik tersebut. Pada proses pembuatan ini tentu saja pelibatan tim mitra sangat penting karena memiliki peran ketika mereka akan mengembangkan desanya secara lebih lanjut. Pada program kemitraan telah terealisasi dalam bentuk perancangan patung hingga pemajangannya di lokasi seperti yang disepakati bersama oleh tim PPDM LP2M bersama mitra.

Pada proses pembuatan ini dimulai dari rancangan konsep, pembuatan gambar desain hingga perwujudan karya. Dalam proses pembuatan seni patung dengan memperhatikan aspek fungsi artistik dan fungsi sosial ekonomi. Fungsi artistik merupakan fungsi penting terkait dengan penambahan kesan keindahan pada suatau kawasan serta penguatan karakter visual yang terbangun melalui karya tersebut (Sun, Wu, Liang, \& Liu, 2013). Fungsi ekonomi adalah untuk menambah daya tarik kepada wisatawan dan calon wisatawan untuk berkunjung kembali di kawasan tersebut karena ada citra artistik. Sehingga dengan meningkatkatnya kunjungan wisatawan yang dipicu daya tarik patung tersebut akan banyak juga pemandu wisata turut mempromosikan kekawasan tersebut. Selanjutnya akan berdampak 
pada peningkatan ekonomi pada kawasan wisata trsebut (Rátz, 2017). Oleh karena itu proses kreatif untuk mengembangkan patung landscape kepada pelaku wisata desa Selorejo perlu ditanamkan. Oleh karena seni patung tersebut sebagai produk artistik ruang publik merupakan kebutuhan pokok dari pengembangan desa wisata. Dengan terpajangnya patung ikon desa wisata yang berbasis pada Eco Culture adalah produk patung yang mampu memperkuat karakter agar desa tersebut agar memiliki keunikan memiliki karakter yang kuat sehingga mendorong tumbuhnya perkembangan wisata di desa wisata yang mengacu pada artistik ruang publik (Andrianus $\square$, Sri Iswidayati, \& Triyanto, 2016).

Hasil kerja kreatif yang didukung oleh mitra sasaran program dalam pelaksanaannya tentu terdapat kendala teknis. Hal ini disebabkan oleh misalnya dasar kemampuan mitra dalam pembuatan karya seni patung yang belum pernah sama sekali. Oleh karena itu dengan adanya kegiatan ini dapat menumbuhkan daya kreatifitas mereka dan ketrampilan teknis yang kelak dapat dilanjutkan secara mandiri maupun komunitas di desanya. Alokasi waktu yang tersedia dalam program ini memang sangat terbatas. Oleh karena itu diharapkan kegiatan ini dapat dilakukan secara berkelanjudan, agar semakin memperkuat pengalaman teknis mereka. Mudah-mudahan kegiatan ini memberi manfaat buat masyarakat pengelola desa wisata Selorejo serta masyarakat wisatawan kawasan tersebut. Pada aspek lain dapat sebagai pemicu kepada para akademisi untuk membantu kelompok masyarakat desa dalam mengembangkan potensinya melalui pengalaman akademik yang diperoleh dari Kampus.

\section{KESIMPULAN}

Program kegiatan PPDM pembuatan karya patung Landscape berbentuk sosok lelaki dewasa bersama dua anaknya yang di pajang di kawasan wisata Agro kultural Selorejo merupakan kegiatan untuk memecahkan permasalahan mitra desa dalam mengembangkan desa wisata di kawasan tersebut. Pada proses pelaksanaannya didukung oleh kelompok masyarakat mitra dan telah terealisasi. Kegiatan kreatif untuk memberdayakan masyarakat melalui kegiatan penciptaan produk seni patung ini, juga dimaksudkan untuk menciptakan ikon visual yang dapat sebagai penguat citra desa wisata berbasis agrocultural. Pelibatan masyarakat menjadi penting karena ketika karya tersebut terujud maka masyaraka merasa memiliki. Patung Landscape yang diciptakan ini memerlukan pemikiran bersama baik dari tim PPDM maupun mitra desa.

Tahapan dalam prosesnya adalah meliputi koordinasi antar tim pelaksana dan tim pengelola desa wisata Selorejo Dau Malang sebagai mitra program. Setelah koordinasi dimantapkan bersama mitra dilanjutkan proses pembentukan karya seni patung. Pembentukan dengan teknik manual melibatkan mitra. Pada proses ini meliputi proses kegiatan pembuatan konstruksi dengan kawat besi konstruksi dan kawat kasa. Selanjutnya proses pembentukan dengan adonan bahan pasir dan semen. Pada proses akhir dengan melakukan pemajangan/display di lokasi kemudian penghalusan karya. Akhir kegiatan dilakukan evaluasi keseluruhan prioses guna mendapatkan masukan dan kritikan terkait dengan proses kreatif yang dihasilkan melalui kerjasama mitra dan tim PPDM.

Hasil dari kegiatan ini adalah patung landscape berbentuk patung naturalis yang terpasang pada kawasan bumi perkemahan desa Selorejo. Hasil kgiatan yang berupa karya seni patung tersebutdidaftarkan ke hak cipta untuk memperoleh sertifikat hak cipta.

\section{UCAPAN TERIMAKASIH}

Kami ucapkan terimakasih kepala LP2M UM yang telah mensuport kegiatan ini, seluruh tim PPDM LP2M UM yang telah turut serta dalam pengembangan kawasan desa tersebut. Tidak lupa kami ucapkan juga terimakasih kepada seluruh tim pengelola desa wisata Selorejo, Dau Malang beserta aparat pemerintahan Desa telah menjadi mitra program tersebut, serta para mahasiswa yang telah membantu lancarnya pelaksanaan kegiatan.

\section{DAFTAR PUSTAKA}

Andrianus, Sri Iswidayati, \& Triyanto. (2016). Patung Pantak Dayak Kanayatn:Kajian Bentuk dan Fungsi dalam Perubahan Sosial Budaya. Catharsis:Journal of Arts Education, 1(1), 135-141. 
Angelini, F., \& Castellani, M. (2019). Cultural and economic value: A critical review. Journal of Cultural Economics, Voume 43(Issue 2), 173-188.

Beardsley, J., \& Finn, D. (1996). A landscape for modern sculpture: Storm King Art Center (2nd ed). New York: Abbeville Press.

Cerisola, S. (2019). A new perspective on the cultural heritage-development nexus: The role of creativity. Journal of Cultural Economics, 43(1), 21-56. h

Chen, H., \& Rahman, I. (2018). Cultural tourism: An analysis of engagement, cultural contact, memorable tourism experience and destination loyalty. Tourism Management Perspectives, 26, 153-163.

Costa, J., \& Ferrone, L. (1995). Sociocultural perspectives on tourism planning and development. International Journal of Contemporary Hospitality Management, 7(7), 27-35.

Darbellay, F., \& Stock, M. (2012). Tourism as complex interdisciplinary research object. Annals of Tourism Research, 39(1), 441-458.

Dharsono. (2016). Kreasi Artistik: Perjumpaan Tradisi Modern dalam Paradigma Kekaryaan Seni, Karang Anyar. Surakarta: LPKBN Citra Sains.

Diah, Pratiwi. (2016). Humanisme karya seni patung abstrak simbolik. Jurnal ilmiah cakra manggilingan, 1.

Ebejer, J. (2019). Urban heritage and cultural tourism development: A case study of Valletta's role in Malta's tourism. Journal of Tourism and Cultural Change, 17(3), 306-320. https://doi.org/10.1080/14766825.2018.1447950

Healy, R. G. (1994). Tourist merchandise' as a means of generating local benefits from ecotourism. Journal of Sustainable Tourism, 2(3), 137-151.

IImi Solihat. (2017). Makna Dan Fungsi Patung-Patung Di Bundaran Citra Raya Kabupaten Tangerang Provinsi Banten (Kajian Semiotika Charles Sanders Peirce). Jurnal Membaca, 2 Nomor 2. Retrieved from

Ponimin. (2019). Themed Figurative Ceramic Artistic Creation from Local Culture Inspiration. KnE Social Sciences, 3(10), 280.

Rátz, T. (2017). 'Be global, go local' - innovation and creativity in the development of alternative guiding services in Budapest. Journal of Tourism and Cultural Change, 15(5), 476-489.

Rendy Widi Prasetyo, \& Nur Wakhid Hidayatno. (2017). Analisis Visual Patung Roro Kuning Di Tempat Wisata Air Terjun Roro Kuning Kabupaten Nganjuk. Jurnal Pendidikan Seni Rupa, 1-10.

Rowland, D., \& Biocca, F. (2002). Evolutionary Cooperative Design Methodology: The Genetic Sculpture Park. Leonardo, 35(2), 193-196.

Sukaya, Y. (2009). Bentuk Dan Metode Dalam Penciptaan Karya Seni Rupa. 1, 16.

Sun, G.-D., Wu, Y.-C., Liang, R.-H., \& Liu, S.-X. (2013). A Survey of Visual Analytics Techniques and Applications: State-of-the-Art Research and Future Challenges. Journal of Computer Science and Technology, 28(5), 852-867.

Warren, S. (2013). Audiencing James Turrell's Skyspace: Encounters between art and audience at Yorkshire Sculpture Park. Cultural Geographies, 20(1), 83-102. 012458397

Wiradimadja, A. (2018). KEARIFAN LOKAL MASYARAKAT KAMPUNG NAGA SEBAGAI WUJUD MENJAGA ALAM DAN KONSERVASI BUDAYA SUNDA. Jurnal Sosiologi Pendidikan Humanis, 3(1), 1-8. https://doi.org/10.17977/um021v3i1p1-8

Wiradimadja, A., Rakhman, M. A., \& Pratiwi, P. (2018). Nilai-Nilai Karakter Sunda Wiwitan Kampung Naga sebagai Bahan Pembelajaran IImu Pengetahuan Sosial. Jurnal Pendidikan Sejarah Indonesia, 1(1), 103-116.

Xu, H., Huang, X., \& Zhang, Q. (2018). Tourism development and local borders in ancient villages in China. Journal of Destination Marketing \& Management, 9, 330-339. 